\title{
PROTECTION OF HUMAN RIGHTS IN EUROPEAN COMPETION LAW
}

\section{E. D. Ungureanu}

\section{Diana Elena Ungureanu}

Christian University Dimitrie Cantemir, Juridical and Administrative Sciencies Faculty Judge, Court of Appeal Piteşti, Trainer, National Institute of Magistracy *Correspondence: Diana Elena Ungureanu, 53 "Regina Elisabeta" Blv., Sector 5, Bucharest, Romania

E-mail: dianaungureanu2004@yahoo.com

\section{Abstract}

One of the most common defenses raised by businesses inspected by the Commission relates to violations of privacy, correspondence and home, protected by article 8 of the Convention, namely that the Commission's investigative powers, often regarded as excessive or exorbitant discretionary do not meet the standard of "necessary measure in a democratic society", set out in article 8 paragr. 2 of the Convention to justify interference under paragr. 1 .

Key words: competition, inspections, the right of privacy, correspondence and home, art.8 E.C.H.R.

\section{Introduction.}

"Guardian of European competition policy" European Commission (the Commission) is entrusted and, consequently has the properly instruments of the effective application of Community competition law.

In order to ensure the effective application of Community competition law, enhanced investigative powers of the European Commission and national competition authorities, under Council Regulation (EC) no. 1/2003 of 16 December 2002 implementing rules on competition laid down in art. 81 and 82 of the Treaty establishing the European Community (now art.101, 102 TFEU) raised many issues in terms of rights enshrined in the Convention (European) Human Rights and Fundamental Freedoms (hereinafter the Convention) in particular Article 6 and Article 8.

\section{The European autonomous notion of "home".}

One of the most common defenses raised by businesses inspected by the Commission relates to violations of privacy, correspondence and home, protected by article 8 of the Convention, namely that the Commission's investigative powers, often regarded as excessive or exorbitant discretionary do not meet the standard of "necessary measure in a democratic society", set out in article 8 paragr. 2 of the Convention to justify interference under paragr. 1.

This defense was first invoked in National Panasonic. In this case, two Commission officials arrived without notice at the point of sale Panasonic, having a Commission decision authorizing an unannounced inspection of all company documents. The inspection began without company lawyer, who arrived three hours later and lasted seven hours, the two Commission officials raising officials copies of documents and notes. Panasonic challenged this procedure, alleging breach of Article 8 of the Convention. European Court of Justice (hereinafter ECJ) ruled in that case that the inspection powers of the Commission under Regulation 17/62, the first Regulation implementing Articles 81 and 82 TEC, which allows it 
to conduct an investigation without prior notice does not defeat any rights arising from Article 8 of the Convention, since they are provided by law and necessary in a democratic society for the preservation of the community's economic welfare.

Three decades after the first judgment, it is still questionable whether the protection offered by the ECJ against the arbitrary use of powers conferred on it by Chapter $\mathrm{V}$ of Council Regulation (EC) no. $1 / 2003$ is equivalent to the protection afforded by the Convention in the light of the right to privacy, correspondence and home. This question becomes especially relevant because, even in its Preamble, the new Regulation 1/2003 states that he "(...) respects fundamental rights and observes the principles recognized in particular by the Charter of Fundamental Rights of the European Union".

2.1.Applicability of Article 8 ECHR to professional offices. The provisions of art. 8 para. 1 of the Convention guarantees the right to privacy, correspondence and home.

For the purposes of art. 8 of the Convention, this right includes the right of individuals to have a home, a place that is freely chosen, where to carry personal life permanently protected from unwanted interference from others.

Both privacy and family life and the right to correspondence are in strong correlation with the notion of the residence of a person.

Domicile is usually defined as the physical space where a person pursues his private or family life.

From the perspective of the ECHR jurisprudence, the concept of "home" in the sense of Art. 8 of the Convention, however, is an autonomous concept which is not limited to homes that are occupied or acquired legally. Qualification of a particular area as home for the purposes of art. 8 actually depends on the specific circumstances of each case being considered, in particular the existence of a sufficient and continuous links with a particular place. The concept of home has a broad interpretation of the ECHR, is included in the broad concept of privacy. Therefore, what it has to be protected is the place where a person could legitimately expect to not be bothered by the authorities or other intruders.

The Court of Luxembourg raised firstly the issue of applicability of Article 8 of the Convention, in the context of an economic opposition to a Commission inspection, under the scope of Regulation nr.17/62. In 1987, the Commission decided to conduct a investigation of chemical companies producing chemicals and polyethylene, including the German company Hoechst. Inspections were carried out on three occasions: firstly, the Commission officials were accompanied by officials of the national competition authority, secondly they were also accompanied by two policemen but they left, saying that a search warrant is needed. Then NCA addressed to the competent national court in order to obtain the warrant, but the application was rejected, the court arguing that no fact likely to establish a presumption of the existence of agreements or concerted practices was provided.

Finally, the Commission obtained a warrant, but the search took place just over two months. Hoechst appealed the Commission decision imposing a fine for non-compliance with the Commission's investigation, arguing that it was contrary to Article 8 of the Convention, as it had been issued no judicial warrant. E.C.J.stated that Article 8 does not apply to commercial establishments, only private dwellings of natural persons.

Hoechst case was reaffirmed by E.C.J. in cases Dow Benelux and Dow Chemical Iberica. Moreover, in case Limburgse Vinyl Maatschappij NV and others against the Commission, the applicants alleged that the inspections carried out by the Commission breached the principle of inviolability of the home, as enshrined in Article 8 of the Convention, but the ECJ stated that "the fact that the ECHR jurisprudence relative to the applicability of Article 8 of the European Convention businesses changed after the cases Hoechst, Dow Benelux and Dow Chemical Iberica has no direct implication on the considerations of the solutions adopted in these decisions".

But, in the ECHR case law, the residence acquires new meanings, widening its scope and covering the place where a person carries his professional activity and, within certain 
limits, the offices and agencies of companies. In this regard, it was stated by the doctrine that we are witnessing the consecration of a "commercial private lives".

In this purpose it should be mentioned the Strasbourg Court decsions in the cases Kopp v. Switzerland and Niemietz v. Germany.

In the first case, E.C.H.R. found that the business premises such as offices of attorney (law firm in this case Kopp and associates), are part of the person's home, being under the scope of notion of privacy.

With regard to the second case, the plaintiff (attorney Niemietz) complained that the search conducted by the judicial authorities in his law office is a violation of art. 8 of the Convention, because damaged his cabinet clientele and reputation as a lawyer.

The German government denied the existence of interference, arguing that art. 8 of the Convention defines a border between private life and home, on the one hand and business premises, on the other hand.

E.C.H.R. held that there is no reason not to include under the scope of the notion of privacy the professional or business activities. In the case of a liberal profession, their work may be part of their lives to such an extent that it is impossible to distinguish in what quality they work at a time.

Regarding the English word "home" in the context of art. 8, the European Court found that in some Contracting States, including Germany, it is recognized that it is extended to business premises. Moreover, this exegesis comes in full agreement with the French version of the text, whereas the term "domicile" has a wider connotation than the home and may include, for example, the office of a person performing a profession, such as the lawyer. Also, E.C.H.R. noted that, in general, to interpret the words "privacy" and "home" as including certain professional or business activities or premises would answer to the essential object and purpose of art. 8 to protect the individual against arbitrary interference of the authorities.

So, the professional premises can be included in the concept of "home" in the sense of art. $8 \mathrm{ECHR}$ and the Court considered that the rights disputed were ignored considering the conventional rules.

This interpretation is further confirmed in the case of Sociéte Colas Est and others against France, where the ECHR tooking into account the dynamic interpretation of the Convention, as living instrument, which must be interpreted in the light of current living conditions, considered that it is the time to recognize that, in certain circumstances, the rights guaranteed by article 8 paragr. 2 of the Convention may be interpreted as including the right of a company to respect its registered office, its agencies and professional venues.

After hesitations in causes Hoechst and Dow Chemical Iberica, ECJ followed the case law of E.C.H.R. in the cases Société Colas Est and others and Niemietz v. Germany v. France and extended the protection afforded by the right to respect the home and the headquarters of companies in cases concerning a search at the premises of this company in competition law investigations by the Commission. The development of jurisprudence of E.C.J. aimed at ensuring the EU law effective protection against arbitrary or disproportionate intervention by public authorities in the sphere of private activities of individuals or businesses.

The argument that Article 8 does not apply to commercial premises can not survive subsequent to jurisprudence Niemietz and Société Colas. Following this case, the exercise by the Commission of inspection powers conferred by Article 20 of Regulation no. 1/2003 constitutes an interference within the meaning of article 8 paragr. 1 of the Convention. Therefore, the question is whether the procedure "raids" of the Commission are justified according to the criteria set out in article 8 paragr. 1 of the Convention and, in particular, if it meets the requirement of proportionality to constitute" a necessary measure in a democratic society".

\section{Inspections national competition authorities and the Commission. Possible interference and its justification}


a) Inspections at the premises of undertakings. According to paragraph 2 of Article 20 of Regulation 1/2003, the officials and other accompanying persons authorised by the Commission to conduct an inspection are empowered: to enter any premises, land and means of transport of undertakings and associations of undertakings; to examine the books and other records related to the business, irrespective of the medium on which they are stored; to take or obtain in any form copies of or extracts from such books or records; to seal any business premises and books or records for the period and to the extent necessary for the inspection; to ask any representative or member of staff of the undertaking or association of undertakings for explanations on facts or documents relating to the subject-matter and purpose of the inspection and to record the answers.

As noted above, subsequent to jurisprudence Niemietz and Société Colas, the exercise of the Commission's powers of inspection conferred by Article 20 of Regulation no. 1/2003 constitutes an interference within the meaning of Article 8 of the Convention paragr. 1. Consequently, the criteria identified above are also relevant in order to check the compliance with the conditions required to justify the interference and to determine whether the "raids" of the Commission are justified, according to the criteria of paragr. 2 Article 8 of the Convention and, in particular, whether these meet the requirement of proportionality to constitute "a necessary measure in a democratic society".

E.C.H.R. conducted a first analysis of this requirement for an inspection in a competition case in Société Colas Est and others against France. For the justification for the interference, the Strasbourg Court held that the investigative powers of the national competition authority had a legal basis and pursued a legitimate aim, namely "economic welfare of the state" and "crime prevention". However, E.C.H.R. found that the inspections were not necessary in a democratic society, in terms of providing adequate and effective guarantees against abuse. The competition authorities had very wide powers which, under the law, it confers exclusive jurisdiction to determine the appropriateness of the number, duration and scope of inspections. Moreover, those inspections had taken place without a prior warrant issued by a judge without a police officer being present.

In light of the conflict between the two European courts, the ECJ decided, finally, in case Roquet Frères, to support the position of Strasbourg. Thus, under the old regime introduced by Regulation nr.17/62 in preliminary ruling in Case C-94/2000, Roquet Frères SA v. Commission, the ECJ especially stated on the interpretation of art. 14 of this Regulation, in particular on the scope of the inspection powers of the Commission, national competition authorities' obligation to provide assistance and the powers of national courts when they are asked to authorize the entry into the premises of economic operators.

In this case, E.C.J. looked particularly where economic operators oppose inspections by the Commission and must ensure penetration into force in such areas, requiring the assistance of national competition authorities and sometimes judicial authorization issued by the competent national court. Such authorization may be required to ensure the efficient preventive inspection. E.C.J. found that, once invested with a request for authorization of an investigation without the cooperation of the respective entity, so that involves entering into force in an enclosure, the national court must determine whether coercive measures ordered are not arbitrary and are proportionate to the investigation. The national court can not rule on the need for an inspection ordered by the Commission to review the legality of the Commission decision is subject to review only by the ECJ.

E.C.J. stated that, in accordance with art. 14 para. 3) of Regulation No 17/62, the Commission must give reasons for the decision which has an inspection, stating its purpose and object.

First, the measures taken to verify the effective conduct an inspection are not arbitrary, the court must determine whether there is evidence of an infringement of competition rules by the economic agent. Commission must show the court that he has evidence. The court can not claim to be submitted to the information and evidence available to the Commission's file, 
which its suspicions are unfounded. E.C.J. stressed in this regard that it is particularly important that the Commission to ensure the anonymity of certain bodies of its information sources to ensure the prevention of anti-competitive practices.

Second, to verify that measures taken are proportionate to the survey, the national court must determine that such measures do not constitute the aim pursued, a disproportionate and intolerable interference.

In this respect, the national court must indicate:

- Essential aspects of the infringement, namely at least supposed to be affected market description and nature of the alleged restriction of competition, without being absolutely necessary to define precisely the relevant market to determine the exact legal nature of the breach or to indicate the period where the infringement occurred;

- The way in which it is assumed that the operators concerned are involved in the violation;

- Evidence sought, in the most precise and inspection powers conferred on the Commission representatives;

- If the assistance of the national authorities is required as a precautionary measure to counter opposition to the economic question, such explanations to convince the national court that, without prior authorization, would be difficult or impossible to determine violation. E.C.J. also held that, where the information provided by the Commission do not meet these conditions, the national court may reject the application. It is obliged, without delay, inform the Commission and the national authority which made the request on behalf of the Commission over these difficulties and possibly require further explanations to enable it to properly consider the request.

Information provided by the Commission may be included in the decision making inquiry or request for assistance submitted in a national or in a response to a question from the national court.

The findings of this case have been integrated in the new regulation, some of Regulation 1/2003, reproducing passages full of case-law cited.

However, the doctrine considers it difficult to sustain the inspection powers conferred by Regulation 1/2003 the Commission shall be accompanied by sufficient guarantees to pass the standard set by the ECHR Case Société Colas Est and others against France, and Roquette Frères jurisprudence that success was short-lived one.

According to paragraph 4 of Article 20 of Regulation 1/2003, undertakings and associations of undertakings are required to submit to inspections required by the Commission's decision. The decision shall specify the subject matter and purpose of the inspection, appoint the date of commencement thereof and indicate the penalties provided for in art. 23 and 24 and the right to have the decision reviewed by the ECJ. The Commission shall take such decisions after consulting the competition authorities of the Member State in whose territory it is to be conducted.

When the officials and other accompanying persons authorized by the Commission find that an undertaking opposes an inspection ordered pursuant to this Article, the Member State concerned shall provide them the necessary assistance, requesting where appropriate the assistance of the police or of an equivalent enforcement authority so as to enable them to carry out inspection and if this support requires authorization from a judicial authority according to national rules, an application for such a permit, according to article 20 paragraph 7. You can submit an application for such a permit, and as a precautionary measure.

In the latter case, national courts may check only the Commission decision is authentic and that the coercive measures envisaged are arbitrary or excessive having regard to the inspection. When checking the proportionality of the coercive measures, the national judicial authority may ask the Commission, directly or through the Member State competition authority, for detailed explanations, especially the reasons for suspecting infringement Commission art. 81 and 82 TEC and the seriousness of the suspected infringement and the 
nature of involvement of the undertaking concerned. However, the national court may question the necessity for the inspection nor demand that it be provided with information in the Commission's file. The legality of the Commission's decision may be reviewed only by the ECJ (Art.20 alin.8). The first issue raised by these provisions in the light required by the Société Colas Est due for inspection compliance with article 8 is that, without a judicial authority in the proper sense of that term, the Commission is empowered to order investigation itself unexpected, according to article 20 paragraph 4 of the Regulation. A second problem is that it ordered an investigation without prior judicial authorization.

There are authors who argue that there is no problem in this regard since it can oppose undertaking investigation and if this happens, the national court approval is required, and the ECJ may still review the legality of the Commission decision was imposed inspection. However, the above arguments do not take into account the fact that as long as that undertaking does not preclude investigation, inspections authorized by the Commission shall remain an independent judicial authority. In addition, national courts are called upon to authorize inspection if an opposition, not to question the need for inspection, may check only the Commission decision is authentic and that the coercive measures envisaged are arbitrary or excessive (Art.20 alin.8) which can not constitute a guarantee of effective judicial authorization.

Finally, the fact that E.C.J. may review the legality of the Commission decision was required control inspection ensures only a posteriori, after the inspection has taken place, contrary to the ruling in the case of Société Colas Est, the ECHR imposed a priori requirement of a judicial warrant. Also, the presence of officials from national competition authority is not equivalent to the presence of the police officer referred to the ECHR Case Sociéte Colas Est. One building still uncertain legal doctrine envisioned a possible remedy for this shortcoming, as a specialized community courts (EC Competition Court) to ensure ex-ante control of the Commission's decisions on inspection. Such a mechanism would be an instrument of centralization of competition policy whose central idea was just decentralization reform.

However, this tool may prove useful in the investigation of multinational cartels in different states require inspections and therefore possibly the issuance of judicial warrants in as many states.

The new rules further specify regarding the possibility of the court to require detailed information on the Commission's reasons for suspecting infringement of art. 81 and 82 TEC, the seriousness of the suspected infringement and the nature of involvement of the undertaking concerned, without being able to ask to be provided with information in the Commission's

file.

A recent example of the case where it claimed that it (the Commission) has not fulfilled its obligation to provide the national court with sufficient information for it to be able to determine if the inspection is arbitrary or contrary to the principle of proportionality is because France Telecom.

This case brings some very important details in terms of understanding the principle of proportionality in the interest case.

Court of First Instance (CFI) reiterates that the principle of proportionality, which is one of the general principles of Community law, requires that measures adopted by Community institutions do not exceed what is appropriate and necessary for the purpose intended, it being understood that, when choice between several appropriate measures, recourse must be had to the least onerous, and the disadvantages caused must not be disproportionate to the aims pursued.

In the area of interest case, the principle of proportionality requires that the inspection does not cause unacceptable inconvenience and disproportionate to the aims pursued by the inspection in question.

However, the choice between the Commission must make the inspection carried out on a simple authorization and inspection ordered by a decision does not depend on the 
particular circumstances such as the seriousness of the situation, extreme urgency or need for absolute discretion, but needs a research appropriate, given the particular circumstances. As a result, when an inspection decision only designed to allow the Commission to gather the elements needed to assess the possible existence of an infringement of the Treaty, such a decision infringes the principle of proportionality.

T.P.I. concludes that it is for the Commission to decide in principle whether certain information is required to be able to detect a violation of the competition rules and, even if it already has evidence or even evidence of the existence of an infringement, it is legitimate that the Commission deem it necessary to have additional checks allow him to better appreciate infringement or duration.

b) inspections in other areas. If the inspection cover a non-commercial setting, Article 21 of Regulation 1/ 2003 provides that the authorization required by a national court, before the Commission inspection decision can be made.

Thus, if there is a reasonable suspicion that certain records or other records and the inspection activity, which may be relevant to prove a serious violation of art. 101 or 102 TFEU, are kept in any other premises, land and means of transport, including the homes of directors, managers and other staff members undertakings or associations of undertakings concerned, the Commission may, by decision, conduct an inspection locations, specifying therein the object and purpose of the inspection, the date when indicating right to have the decision reviewed by the Court of Justice and in particular the reasons that led it to conclude that there is no such suspicion.

The Commission shall take such decisions after consulting the competition authority of the Member State where it is to be conducted.

In this case, the national court verifies that the Commission decision is authentic and that the coercive measures envisaged are arbitrary or excessive having regard in particular to the seriousness of the suspected infringement, weight of evidence investigated the involvement of the undertaking concerned and acceptable probability that the records and registers business related to the inspection to be kept on the premises for which the license. The national court may ask the Commission, directly or by the competition authority of the Member State concerned, detailed explanations on those elements that are necessary to enable it to verify the proportionality of the coercive measures envisaged.

However, the national court may, in this case, to question the necessity for the inspection nor demand that it be provided with information in the Commission's file. The legality of the Commission's decision may be reviewed only by the ECJ.

Extension of inspection powers of the Commission and to other places than the head company can raise more serious problems in terms of justifying interference, ie the conditions for the" necessary measure in a democratic society".

This condition is evaluated differently in ECHR when it is compared to private home professional office. Thus, Niemietz, E.C.H.R. suggests a double standard, showing that the interference justified under article 8 paragr. 2 of the Convention can go far when it comes to professional or commercial offices, which means greater protection for private homes. First, if these inspections without a judicial warrant is a particular concern when searching private homes. If the requirement of a judicial warrant is of particular importance in this case, however, it is not a decisive factor in itself.

If the requirement of a judicial warrant is of particular importance in this case, however, it is not a decisive factor in itself. Thus, Niemietz, cited above, a search warrant was drafted in broad terms, providing search and raising documents without any limitation in order to reveal the identity of the writer offensive ECHR concluding that the manner of conducting the search has led to violation of professional secrecy to an extent disproportionate to the aim pursued.

Second, as noted above, to consider the criteria established by the Strasbourg Court that pass inspection "proportionality test". 
At first glance, Article 21 of the Regulation appears to provide sufficient guarantees: First, authorization by a national court is required before a Commission inspection decision can be made. Secondly, the Commission may adopt a decision only if there is a reasonable suspicion that certain records or other records and the inspection activity, which may be relevant to prove a serious violation of art. 101 or 102 TFEU, are kept in any other premises, land and means of transport, including the homes of directors, managers and other staff in undertakings or associations of undertakings concerned. Thirdly, the Commission shall specify therein the reason that led it to conclude that there is no such suspicion. Fourth, the Commission's investigative powers are limited to business books and records. Finally, if the national court has the same powers to check the Commission's decision stated in article 20, paragraph 3 in Article 21 assigns special powers to check: the importance of researched evidence (...) and the acceptable probability that the records and registers related to the inspection to be kept on the premises for which the license.

However, even in this case the guarantees provided by regulation can not be considered safe from any criticism.

The national court may, in this case, to question the necessity for the inspection nor demand that it be provided with information in the Commission's file. In this regard, one can not speak of a true national court authorization by the Commission for inspection in private homes.

Furthermore, it is possible to E.C.H.R. inspection to appreciate the power of households' directors, managers and other personnel enterprises "exceed the limits of what a competition investigation should aim: the discovery of violations of competition rules by businesses. Might consider that extending these inspection powers homes of directors is allowed, but extending them to anyone working for the enterprise has a purpose too wide.

\section{Conclusions.}

Very broad coercive powers of the Commission in proceedings concerning competition law, particularly the authority to investigate and conduct searches, remains a fertile source of litigation in which the general principles of law and fundamental rights have often been invoked to challenge executive and administrative action of the Commission, the parties affected repeatedly asking the Court of Luxembourg to limit and control the exercise of these powers by reference to fundamental principles of law.

However, out of the 30 cases of EU competition law that have raised issues concerning human rights, the conclusion that emerges is that EU courts avoided as much as possible to rule in favor of arguments based on the text of the Convention or the ECHR jurisprudence.

\section{Bibliography}

F. Rizzuto, Parallel Competence and Power of the EC Commission under Regulation 1/2003 According to the Court of First Instance, European Competition Law Review, 2008, 29 (5), p. 286-297.

D. J. Gerber, P. Cassinis, The "Modernisation" of European Community Competition Law: Achieving Consistency in Enforcement: Part 2, European Competition Law Review, 2006, 27 (2), p. 51-57.

C. Diemer, Green Paper on Damages actions for breach of the EC antitrust rules şi John Pheasant, Damages actions for breach of the EC antitrust rules: The European Commission's Green Paper, în European Competition Law Review, 2006, 27 (7), p. 365-381

R. Wainwright, The Relationship between the National Judge and the European Commission in Applying Articles 81 and 82 of the EC Treaty, în ERA-Forum I/2004, p. 84-91.

C. Brown, D. Hardiman, Case Comment, The Extent of the Community Institutions' Duty to Co-operate with National Courts- Zwartfeld Revisited, în European Competition Law Review, 2004, 25 (5), p. 299-304. 
K. Pijetlovic, Reform of EC Antitrust Enforcement: Criticism of the New System is Highly Exaggerated, în European Competition Law Review, 2004, 25 (6), p. 356-369.

J. Mischo, L'autorisation des inspections, ERA-Forum I/2004, p. 92-102.

Adriana Andreangeli, Courage Ltd c. Crehan and the Enforcement of Article 81 EC before the National Courts, în European Competition Law Review, 2004, 25 (12), p. 758-764.

A. Riley, EC Antitrust Modernisation: The Commission Does Very Nicely- Thank you!, Part 2: Between the Idea and the Reality: Decentralization under Regulation 1, European Competition Law Review, 2003, 24 (12), p.657-672;

D. Brault, Politique et pratique du droit de la concurrence en France, L.G.D.J., Paris, 2003, p. 521-526.

M. Voicu, Considerații succinte asupra Regulamentului 1/2003 cu privire la aplicarea regulilor de concurență prevăzute de art. 81-82 din Tratatul Comunității Europene, Revista de Drept Comunitar 7-8/2003, p. 289-305. 